\title{
A CASE STUDY ON CENTRALISED SECURITIES DEPOSITORY FOR EQUITIES MARKET IN EMERGING COUNTRIES IN THE FAR EAST
}

\author{
M Field \& R W E van der Wal (Technikon Witwatersrand)
}

\begin{abstract}
This report has analysed the effect that a Centralised Securities Depository (CSD) for equities will have on the securities industry in the emerging countries of the Far East. The first part of this report dealt with the securities industry and its environment and identified the most important factors influencing the industry. In addition, the experiences of custodian banks in selected Far Eastern countries were ascertained in relation to the establishment of CSDs in these countries. From this base, using available data and assisted by various experts, the most likely trends have been used to predict the effect that a CSD for equities will have on the securities industry in South Africa.
\end{abstract}

\section{INTRODUCTION}

In order to reduce risk and improve efficiency in the South African equities market, while simultaneously introducing international settlement standards, the Johannesburg Stock Exchange (JSE), in consultation with all role players in the banking and insurance industry is working towards the establishment of an initiative known as STRATE, an acronym for Share TRAnsactions Totally Electronic. Singer (1997) Project Manager of STRATE says that the initiative is a new electronic settlement system for transactions in South African equities. Equity certificates will be a thing of the past when a paperless CSD is established, and transfer of ownership is effected by electronic book entry.

The electronic settlement system is vital to bring South Africa in line with international practice and to enhance the security and efficiency of settlement in the South African market, says Singer (1997).

\section{THE CURRENT SYSTEM OF SHARE MARKET TRANSACTIONS IN SOUTH AFRICA}

The current market settlement system is archaic and fraught with financial risks (Cole 1997). The present system involves stockbrokers who act for the buying and selling parties. Custodian banks who hold the physical share certificates in their vaults are then instructed by the selling stockbroker, on behalf of his client, to remove the share certificates in respect of the sale from the vault and hand these over, in addition to a signed transfer deed, to the stockbroker acting on behalf of the buying party. This transaction can only be effected if the stockbroker acting on behalf of the buying party hands over a cheque for the purchase price at the same time. The custodian bank of the selling party then banks the cheque into the selling client's bank account, whilst the custodian bank of the buying party will 'on deliver' the certificate and the signed transfer deed to the Company Registrar in order to register the name of the new owner of the shares into the company's records. If this process occurs without problem the whole transaction may be completed in two weeks. If there are delays on any side the process may take months, explains Jeanette Cole, Divisional Consultant with Standard Corporate and Merchant Bank (Cole 1997). The risk that one leg of this extended transaction fails, is quite real and therefore a risk of non receipt of ownership by the purchaser or non- receipt of cash by the seller is not an impossibility.

There is a danger that the share certificate is a forgery, and this will only be discovered at the Company Registrar, once the cheque has been paid; or the share certificate may be handed over in return for the cheque, which is then dishonoured by the paying bank. Either the share certificate or the cheque can be lost or stolen in transit between the parties involved and when these transactions amount to millions of Rands the international investing companies become nervous. The need for an electronic CSD has 
become imperative to reduce these risks in the settlement system, streamline the process and reduce the time frame from weeks to minutes (Cole 1997).

While the current system of settlement of share transactions in South Africa adequately performs the task at hand, it is nevertheless outdated in relation to modern day practices in international markets. It also maintains all the risks and inefficiencies inherent in a paper-based system. Share certificates circulating in the market place, by the means of physical delivery, carry with them the risk of fraudulent action, loss and theft whilst requiring the maintenance of cumbersome administrative processes. The overall costs within such an environment tend to be higher than with an electronic settlement system (Singer 1997). The need to establish a CSD for equities in South Africa will therefore have the benefits of a reduction in administrative costs and improvement in efficiency.

\section{SECURITIES DEPOSITORY SYSTEM}

Central Securities Depositories (CSDS) are no new invention, says Mr. Jens Bache (1997:13), President of VP - the Danish Securities Centre. The Frankfurter Kassenverein was established in 1949 and from the end of the 1960s to the mid 1980s a number of major markets followed and established central securities depositories, and securities clearing agencies. The fact that South Africa is now investigating the implementation of a system that has been in operation elsewhere in some form or another for up to fifty years should demonstrate to international investors that South Africa intends modernising its settlement system.

The Bank for International Settlements (BIS) defines a CSD as a facility for holding securities which enables securities transactions to be processed by book entry. Physical securities may be immobilised by the depository or securities may be dematerialised (i.e. so that they exist only as electronic records.) BIS December 1993 (CSD Review 1997:11).

Central Securities Depositories (CSD's) have emerged as an integral part of the global securities market place. Much has been done by domestic markets to improve the efficiencies and reduce the risks of investment through the creation of local CSD'S. Despite this undoubted progress there is no such entity as a typical CSD, and the investment community should not underestimate the complexity of the subject (Duggan 1997). If there is no such thing as a typical CSD, then South Africa needs to investigate its own local needs in conjunction with those of its international investors, in order to find common ground on what is acceptable to all to reduce settlement risk and become more efficient in securities transactions.

The main feature of the depository system is the procedure applying to the transfer of deposited securities. It is executed on the basis of accurate orders given by the depositor to the clearing corporation whereby purported transfers are debited and credited to the relevant accounts. The number of accounts and sub-accounts shall be consistent with the number of depositors and principals as well as the class and type of deposited securities. Depositors give the CSD instructions to transfer, pledge or withdraw securities. It should be noted that this system facilitates the transfer or pledge of securities with no need for them to be physically delivered or registered in the issuer's records, since transactions are shown by means of book keeping entries in the CSD's records. The CSD is held liable for the loss or elimination of the stock certificates under the custody system, even in the case of unforeseen events, i.e. force majeure or an act of God (Reaves 1997).

In Sweden, securities can be purchased or sold through banks and brokers. All transactions and changes are then registered by the VPC (Vardepapperscentraden AB), the Central Swedish Securities Depository jointly owned by the government and finance and industry institutions. Once a security has been made 
depository eligible for clearing and settlement it is normal that all sell trades in that security must settle out of a depository account. This implies that the appropriate quantity of securities must already have been placed in that account (Reaves 1997). If this method is adopted for the South African CSD the risk of nonsettlement due to insufficient holdings will become a thing of the past.

Global emerging markets such as Thailand, India, and Malaysia all have CSDs operating in the securities industry. So it is important that South Africa can demonstrate the same investor facilities that these countries exhibit. For foreign investors in emerging markets, the thought of trades being lost amid mountains of share certificates is enough to send them running all the way back to the haven of the New York Stock Exchange (Schager 1997:31). Schager continues that, historically, many emerging markets have simply been ignored by foreign investors, because the susceptibility to natural disasters, political instability, poor capital market infrastructure, unreliable sub-custodians, and the inability to trade and settle shares on anything less than twenty days after having struck the deal so often leads to high volatility and money lost.

It has been an uphill battle for many of these developing markets to shed their unkind reputations and find a solution to solidify investment stability and efficiency. The answer to their problem, as often than not is spelled "CSD". Attempting to confront the plethora of physical certificates that plague back-offices, the painfully slow clearing and settlement rates, and the risk involved in trading in such volatile waters, many emerging markets have created (or are creating) a CSD out of existing institutions or, in cases where previous depository functions were spread among a wide variety of different institutions, from scratch, (Schager 1997:31). While setting up a depository may eliminate some of an emerging market's deterrents to luring foreign capital, creating a fully operational, state-of-the-art CSD presents countless difficulties for them. Perhaps foremost among the obstacles involved is making sure those in charge understand what they are doing (Schager 1997:31).

The Inter-American Development Bank's (IDB) Jesse Wright, who recently completed a project setting up CSDs in Central America believes, at least initially, emerging markets should concentrate on immobilisation [certificates still in existence but in a central vault]. Because of historical ties to physical certificates, says Wright, "we're trying to get more and more brokers and their clients to immobilise their physical certificates at the depository" (CSD Review 1997). It would be nice to dematerialise [no physical paper certificate exists, only an electronic record showing share ownership], but it's not as necessary. Not everyone, however, sees immobilisation as a sufficient substitute for papeliess systems. "Once they understand how costly it is to move that piece of paper in the process of trading securities, then they realise that dematerialisation is a benefit"(CSD Review 1997:33).

The ultimate goal of any capital market is to eliminate the security certificate and to rely on electronic record keeping within a Centralised Securities Depository. There are various approaches that can be used to arrive at this ultimate goal, including immobilisation and dematerialisation.

\section{IMMOBILISATION}

Immobilisation is the step which many markets have taken towards the eventual elimination of all security certificates whereby the certificates are deposited into a vault, cancelled and never used in the transfer process ever again. In an immobilisation process there are still security certificates but the certificates are held by or on behalf of the CSD. To reduce the size of the certificate inventory, the concept of "jumbo" certificates is often used. Withdrawals are usually allowed from the immobilised inventory of security certificates and there are often legal reasons why it is necessary to adopt an immobilised depository rather than moving directly to a dematerialised depository (GNA Consulting Group 1997). 
The law in South Africa recognises that a private individual will always have the right to a certificate of title to prove ownership of financial investments. So the CSD will not be completely paperless. However, the value of a certificate held outside the CSD will have curiosity value only, because to effect transfer once the CSD is operative, the paper certificate will require to be housed in the CSD in an electronic form.

\section{DEMATERIALISATION}

In a partially dematerialised environment there are no security certificates held by the CSD, but certificates may still be held by individual investors. In a fully dematerialised environment there are no security certificates either in possession of the CSD or individual investors. Reconciliation of holdings is through a comparison of electronic records maintained by the transfer agent and by the CSD. Resolution of differences is through examination of respective electronic transaction entries. Clearly the degree of reliance that can be placed on the integrity of these electronic records is a major determinant in moving to a dematerialised environment (GNA Consulting group 1997).

\section{INTERNATIONAL CENTRALISED DEPOSITORIES}

South Africa is described as an emerging/developing country and many of the newly emerging/developing countries of the Far East have attracted international investment over the last decade. This investment has been of great benefit to these countries and has allowed their economies to grow, which brings financial empowerment for its citizens. One of the possible reasons that these countries have attracted international investment is that these markets have reduced the flows of physical paper and introduced securities settlement via the establishment of Central Securities Depositories. South Africa is able to learn from experiences in these developing economies in the establishment of its own CSD.

Malaysia is the second most important investor in South Africa after the United Kingdom. Malaysian companies have recently purchased a $30 \%$ stake in South Africa's telephone utility, Telkom, and Petronas of Malaysia has also purchased a 30\% stake in Engen, South Africa's petroleum company. The Malaysian stock market has a similar number of shares listed on the Malaysian Stock Exchange, and a similar market capitalisation to that of the South African market, justifying a comparison. The financial markets of India, Singapore and Hong Kong are also markets that have recently established a centralised depository for equities and previously used similar operating practices to those currently used by the South African securities market, and this is the justification for including these countries in this analysis.

\section{Malaysia}

Under section 14 of the Securities Industry (Central Depositories) Act 1991, the Kuala Lumpur Stock Exchange (KLSE) in Malaysia is empowered to force any listed company or company to be listed into the CSD. Shareholders who do not trade in their shares do not have to deposit; however, if they try to trade, shares must be deposited, as settlement of trade in the CSD is by electronic book entry (Malaysian Central Depository SDI 1994).

The issuance date of the operating license that created the Malaysian Central Depository (MCD) was 14th April 1990. Equities have been fully immobilized since 1st January 1997. The MCD is a private corporate body, a subsidiary of the KLSE. Regulation of the MCD is by the Securities Exchange Commission. The use of the MCD is compulsory and all equities have been immobilised into the MCD. Ownership of the MCD is as follows: 


$\begin{array}{ll}\text { KLSE } & 55 \% \\ \text { Banks } & 25 \% \\ \text { Government } & 20 \%\end{array}$

Since the CDS (Central Depository System) was launched in November 1992, market participants, local and international, have warmly welcomed it. The CDS has provided everyone with an efficient clearing and settlement system with vastly increased capacity. Costs and risks associated with physical settlement have also been reduced (Malaysian Central Depository 1997).

\section{India}

The National Securities Depository Limited (NSDL) received the certification to commence business on 15th October 1996 from the Securities and Exchange Board of India (SEBI).

Ownership of the NSDL is as follows:

Industrial Development Bank of India $\quad 46 \%$

Unit Trust of India $\quad 44 \%$

Stock Exchange $\quad 10 \%$

India is on the brink of a revolution in paperless share-dealing (Guha 1997). This follows a surprise announcement by SEBI, the country's main financial regulator that all institutional investors must hand in their paper shares by 15th January 1998. The move - which has huge implications for India's stock market - marks a sharp reversal of policy. Until the announcement, India had maintained that investors had the right to hold onto paper certificates if they wished.

\section{Singapore}

Ownership of the Central Depository is regulated by the Stock Exchange of Singapore Ltd which also owns the CSD to the extent of $100 \%$. Use of the CSD is compulsory. All equities are immobilised into the CSD. The Central Depository was established in 1987. Singapore introduced the Central Depository (CDP) in 1990 and through a carefully managed transition to a scripless environment, has created a successful and efficient securities market. The CDP does not have a cash clearing capability at present, although it does provide capabilities to block transfer of shares until payments between participants have been effected (Osborne 1997:31).

\section{Hong Kong}

The Hong Kong Securities Clearing Company Limited was incorporated on 5th May 1989, and since June 1992, the Stock Exchange has made it compulsory for trades to be settled through the CSD. Hong Kong Clearing is a limited company, limited by guarantee and a non- profit distributing company. Hong Kong Clearing is a limited liability company guaranteed by its six members. These members are as follows:

The Hong Kong Stock Exchange $\quad 50 \%$

The Bank of China $10 \%$

Hang Seng Bank Limited $\quad 10 \%$

Standard Chartered Bank $\quad 10 \%$

The Bank of East Asia Limited $\quad 10 \%$

The Hong Kong \& Shanghai Banking Corp. $\quad 10 \%$ 


\section{THE INTERNATIONAL QUESTIONNAIRE TO SELECTED FAR EASTERN COUNTRIES}

A questionnaire was sent to custodian banks in the following countries: Malaysia; India; Singapore; Hong Kong.

Custodian banks are banking institutions that provide safe keeping services to institutional investors, and are the major participants in the Centralised Securities Depositories in these countries. All four countries have established a Centralised Securities Depository, during the last decade, for the safe keeping, clearing and settlement of securities and therefore the inclusion of these custodian banks in the questionnaire process is relevant to obtain their experience.

The names of the custodian banks were extracted from the Emerging Markets Directory 1997 listed under the heading of "custodian banks" in the countries previously listed. All names listed were sent a questionnaire by facsimile and a total of 52 custodian banks was used as the population. The 52 custodian banks were distributed as follows:

$\begin{array}{ll}\text { Malaysia } & 11 \\ \text { India } & 8 \\ \text { Singapore } & 15 \\ \text { Hong Kong } & 18\end{array}$

The Emerging Markets Directory is regarded as a publication in which all custodian banks operating in emerging countries are listed, and therefore its use as a source document for custodian banks is representative of the population.

The rationale behind contact to these specific countries was as follows:

- $\quad$ The countries are described as emerging financial markets, South Africa having been shunned for thirty years by the global community is regarded as a re-emerging financial market.

- $\quad$ The financial markets of these countries have recently introduced Central Securities Depositories for equities,

- $\quad$ The countries, Malaysia specifically, have a similar financial market size, and had similar financial market practices to those in South Africa prior to the establishment of their CSD.

The questionnaire was sent by facsimile. The response to this questionnaire was a $31 \%$.

\section{INTERNATIONAL QUESTIONNAIRE}

The answers to the international questionnaire from a sample of 16 are as follows.

Question 1: Your organisation, prior to the establishment of a Centralised Securities Depository (CSD), settled equity trades on a physical basis. Please list the benefits of using electronic settlement for equities in your CSD.

The following detailed responses were given:

a) Reduced staff complement, no need for delivery staff and reduced settlement staff, staff become more efficient $(46,2 \%)$.

b) Elimination of settlement risks, settlement becomes more efficient and timely (53.8\%). 
c) Elimination of lost certificates, forgeries, stolen certificates and fraud as system is paperless (68.2\%).

d) Faster turnaround on registration of trades which allows a greater turnover and increased business using less staff $(36.2 \%)$.

e) Registration costs/scrip costs/office space and overtime costs all reduced. Reduces human error, and reduces paperwork (53.8\%).

Question 2: Referring to your answer to question 1, what are the limitations of electronic settlement for equities in your CSD?

The following detailed responses were given:

a) Rigid cut-off times and procedures imposed by the CSD (23.1\%).

b) Risks involved if the CSD rejects the transfer after the cash has moved or that the CSD makes a mistake - we are reliant on the quality of CSD staff $(8 \%)$.

c) Custodian banks are not linked into the system (Malaysia) (15.4\%).

d) Additional charges and timing problems for urgent "turnaround" processing (15.4\%).

e) Not true delivery versus payment system as cash settles outside the CSD (15.4\%).

Question 3: Once the CSD for equities became operational what was the staff reduction?

The following tally shows the reduction in staff members within broad bands:

No reduction

Reduction by at least $20 \%$

Reduction of $21 \%-40 \%$

Reduction of $41 \%-60 \%$

Reduction of more than $61 \%$

\section{Question 3.1}

If numbers of staff were reduced following the establishment of the CSD, were the surplus staff redeployed within your organisation?

The following responses were given:

Yes $=46 \% \quad$ No $=31 \% \quad$ Not applicable $=23 \%$

The following detailed responses were given:

a) We achieved greater volumes with the same number of staff $-18 \%$.

b) Staff voluntarily moved to other organisations $-9 \%$.

c) Staff have been changed to contract staff $-9 \%$.

Question 4: Has the establishment of the CSD for equities resulted in major changes to the safe custody and settlement industry in your country?

The following responses were received:

Yes $=69 \% \quad$ No $=23 \% \quad$ Don't know $=8 \%$

Question 4.1: If your answer was yes to the above, please explain.

The following detailed responses were received:

a) In a scriptless environment shares are automatically registered, errors are almost eliminated, and failed trades are reduced $(30.8 \%)$.

b) Better control over risk, and an immediate reduction in settlement risk (15.4\%).

c) The settlement process is more efficient and faster which gives the market a better image $(53.8 \%)$. 
d) Market turnover is higher, with greater liquidity which improves investor confidence (30.8\%).

e) Better control over corporate events and reduced claims in the market place (15.4).

Other responses: Fees now under pressure, barriers to entry into market place reduced.

Question 5: Has the time taken to settle an equity trade using the CSD been reduced?

Yes $=55 \% \quad$ No $=45 \%$

Question 5.1: If you answered yes:

(a) what was the standard time prior to the CSD

(b) what is the time now using the CSD

Of the $55 \%$ of "yes" responses, $71 \%$ said that the standard time prior to the use of the CSD was seven days, and when using the CSD it is now five days.

Question 6: Is there a restriction to the types of participants in your CSD. Please explain

Yes $=85 \% \quad$ No $=7.5 \% \quad$ Not applicable $=7.5 \%$

The participants allowed to operate within the CSDs are categorised as follows:
a) Brokers and members of the stock exchange - $\quad 84.6 \%$.
b) Banks
c) Custodian banks and nominee companies
d) Financial institutions
e) Insurance companies
$84.6 \%$.
$53.8 \%$.
$30.8 \%$.

Question 7: Has the percentage of failed equity trades been reduced following the introduction and use of the CSD?

Yes $=69 \% \quad$ Don't know/unable to tell $=31 \%$

Question 8: If so, by how much?
a)
b)
Do not know -
c) Between $15 \%-25 \% \quad-\quad 8 \%$
d) By $50 \%$

Question 9: Have fees charged to clients by custodians been impacted by the use of your equities CSD. Yes $=85 \% \quad$ No $=7.5 \% \quad$ Not applicable $=7.5 \%$

\section{Please explain.}

a) Fees have been forced down because of no vault space required, reduced manual processing,

and fewer staff employed has resulted in lower operating costs (15.4\%).

b) Lower transaction costs, and greater market volumes have allowed costs savings to be passed onto the clients (15.4\%).

c) With reduced costs there is a price war to gain volumes (15.4\%).

d) Electronic efficiency is less costly than manual staff processes $(23.1 \%)$.

e) With electronic settlement there is now more competition as industry entry barriers have been reduced $(68.2 \%)$. 


\section{CONCLUSION}

Custodian banks in the Far Eastern countries of Malaysia, India, Hong Kong and Singapore were canvassed on the benefits achieved once a CSD had become operational. Their views were that the major benefits of a CSD were the removal of paper share certificates resulting in the elimination of lost share certificates, reduced thefts of the same, reduced forgery and fraud expenses. Costs of settlement have been substantially reduced because of the electronic system and of reduced levels of staffing, and by the fact that staff is now able to be more productive and efficient. The rigid rules, regulations and deadlines are regarded as a limitation in the use of the CSD.

Of the respondents polled, $45 \%$ said that staff numbers did not reduce after the introduction of a CSD. Since the establishment and operation of a CSD, the markets have increased their turnover and achieved greater liquidity, which has improved investor confidence in their market. Overall, the markets in which a CSD is operational, have a better international image. On the matter of compulsory usage of the CSD, $73 \%$ of respondents explained that it was compulsory to use the CSD as a settlement mechanism, but investors still had the right to hold shares in paper form.

A major problem that is experienced by two markets is that cash transactions are not a function of the CSD, and therefore true delivery versus payment can not be achieved. With a CSD operational in the securities market the barriers to entry for a custodian bank have been reduced and correspondingly, there is more competition which has resulted in lower prices for services provided.

The aim of this article was to ascertain whether a CSD for the equities market in emerging/developing countries in the Far East have indeed be for the better.

\section{Reducing Settlement Risk}

In a paper based system of equities settlement, there is risk and the possibility of a financial loss by either the buyer or seller.

The Far East, markets gave the following responses on the question of CSDs being able to reduce settlement risk:

a) The CSD has eliminated settlement risks because settlement becomes more efficient and timely.

b) It has eliminated the previous problems of lost and stolen certificates and frauds because the system is now paperless and electronic.

c) However, the inherent risk within the CSD still remains. If the CSD makes a mistake there is the possibility that the parties involved in the securities trade are open to risk, but certain guarantees contain this possible risk. Risk, therefore, has been substantially reduced.

d) The associated settlement risk can only be reduced once a delivery versus payment system is in place. This has been an integral part of the Singapore CSD since August 1997 and has reduced settlement risk and allows for the simultaneous exchange of securities for same day funds (see 4.3 Q7.1).

\section{Provide a more efficient and effective method of equities settlement than currently exists}

The international respondents to the questionnaire stated that with the elimination of settlement risks, settlement becomes more efficient and timely and 53\% regarded this as the case in the CSD in which they operate. Further agreement to this position is represented by the answer to question 3.3 where $46 \%$ of respondents stated that staff numbers within their organisations were reduced. Eighteen per cent of this 
$46 \%$ (therefore $39 \%$ of the yes category) said that greater volumes of work were achieved with the same number of staff. This in effect is the definition of efficiency (i.e. more output with the same input).

In question 4. 1, 69\% of respondents said that the CSD had resulted in major changes to the safe custody and settlement industry in their countries. Fifty-three percentage of the $69 \%$ (i.e. $78 \%$ ) reported that the settlement process is more efficient, and faster which gives the market a better image.

Seventy seven per cent of respondents are faced with compulsory use of a CSD. The following resulting benefits were mentioned:

- $\quad 23.1 \%$ see this as increasing efficiency in the market place.

- $\quad 15.4 \%$ state that it allows greater volumes to be handled by the market and $30.9 \%$ said that it allows an increase in capacity without an increase in operational costs.

In $55 \%$ of the markets, the time that it takes to settle the transaction has been reduced, and this implies a better market environment.

\section{WHAT IS HAPPENING NOW IN SOUTH AFRICA}

The SAFIRES system (Southern African Financial Instruments Real-time Electronic Settlement system) which underlies all STRATE operations was bought from Switzerland's CSD, Sega Intersettle. It was developed customised and implemented by a highly-experienced team from Tata Consultancy Services of India, the world's largest organisation of its kind. The sophistication of this system will ultimately enable STRATE to seamlessly process an unlimited number of daily transactions without manual intervention. This is referred to as Straight-Through Processing (STP) and is a major goal of the global securities industry. This goal is important as the industry is constantly striving towards shorter settlement cycles (STRATE talking, 2000:6)

\section{RECOMMENDATION}

A comparative study could be done between the Far East and the new South African CSD.

\section{BIBLIOGRAPHY}

BACHE J. 1997. Thomas Murray. London : CSD Guide.

COLE J. 1997. A personal interview with Jeanette Cole, Senior Consultant, Standard Corporate \& Merchant Bank, South Africa.

CSD REVIEW. 1997. Thomas Murray : London.

DUGGAN D. 1997. A framework for understanding securities depositories. ICB magazine, Sept./Oct. London.

GNA CONSULTING GROUP. 1997. Http://wWW.gnaconsult.com.

GSCS BENCHMARKS. The 1997 review of emerging markets. London.

GUHA K. 1997. India on the brink of paperless share dealing revolution. Financial Times, 16 Oct. 
MALAYSIAN CENTRAL DEPOSITORY. 1994. The CDS handbook. $2^{\text {nd }}$ ed. Kuala Lumpur.

OSBORNE AT. 1997. CSDs since G30: how successfully have the recommendations been implemented. London : Thomas Murray.

REAVES MS. 1997. South Africa modernizes its major stock exchange.

http://www.africanews.org/specials/19971104_jse.html. Accessed: 6 May 2000.

SCHAGER N. 1997. Creating emerging market depositories. CSD review. London : Thomas Murray.

SINGER M. 1997. Electronic settlement for the South African equities market. The Shareholders Association of South Africa. Newsletter, 40(4), Oct.

STRATE TALKING. 2000. SAFIRES sophistication. 11th issue.

WALSH JG. 1997. The world's response to the G30 attempt to characterise corporate thinking about the future. London : Thomas Murray. 